\title{
Defining and Prioritizing the Effective Urban Planning Indicators on the Citizenship Rights Achieving by Using AHP (Case Study: Islamic Republic of Iran)
}

\author{
Zohreh Davoudpour, Mohammadreza Sadeghi Moghaddam*
}

Department of Urban Design \& Planning, Qazvin Branch, Islamic Azad University, Iran

Copyright (C) 2015 by authors, all rights reserved. Authors agree that this article remains permanently open access under the terms of the Creative Commons Attribution License 4.0 International License

\begin{abstract}
Formation and institutionalization of sustainable and democratic society requires serious attention to the citizenship rights. Citizenship is a status which is including a set of rights, duties and obligations and emphasis on equality, justice and independence. On the other hand urban has an undeniable role for citizenship rights which will be attained with proper and justice planning. Hence, the primary aim of this study is, Defining and prioritizing the effective urban planning parameters on the citizenship rights. To accomplish the above target, more or less significant concepts such as citizenship, civic rights, urban planning and targets were determined as a theoretical framework by utilizing the analytical method. Then, Islamic Republic of Iran has been studied based on its constitution as a case study. Then the effective urban planning parameters of the citizenship rights were defined and prioritized by using Analytic hierarchy process evaluation method (AHP) and Expert choice software. The results indicate that urban infrastructure and public spaces with a weight of about 70 percent has the highest impact on the citizenship rights.
\end{abstract}

Keywords Urban Planning, Citizenship Rights, Analytic Hierarchy Process Evaluation Method AHP, Islamic Republic of Iran

\section{Introduction}

One of the important issues of today's world is the citizenship rights and citizenship education. Citizenship topics didn't have historical records in the past, but during the past century the importance of it is increasing [1].

Nowadays, urbanization is one of the necessities of our life as social phenomenon. Citizens always are active and working in urban society with different tastes and motivations. Hence, social life requires legal relationships between individuals and different groups in society that should be within the framework of regularity. In recent decades, subjects and issues affected on citizens and citizenship rights were discussed in various countries. And in this regard the views and theories have been proposed. Depending on the circumstances of each country, they're dealing with their particular problems [2].

On the other hand, one of the significant factors of social, political and legal topics of the modern body politic in the contemporary world, is the place and prerogatives of citizenship rights. A new epoch in the historical experience of the human has been over stretched following by, Social changes and political revolutions of the past two centuries and the collapse of the foundation and autocracy, and the issue of novel concepts in political and legal literature. Separate branches of government, restriction of political power and the emergence of constitutions as a general covenant between political authority and citizens is a new horizon in the regulation and transparency in relationships between government and citizens and the rights and privileges of citizens of the new state constitution got the privileged position [3].

In this study, the rights and privileges of the Iranian masses, including different ethnicities and faiths based on Islamic Republic of Iran's constitution were defined as a framework and finally the effective urban planning parameters of the citizenship rights were defined and prioritized by using AHP model.

\section{Methodology}

The Methodology is the general research strategy that outlines the way in which a research project is to be undertaken and, among other things, identifies the methods to be used in it. Having a clear methodology is often deemed important, especially in the sciences. Clearly outlined directions and procedures tend to increase consistency, and to create work which can be repeated elsewhere, which is an important characteristic of rigorous scientific research. In this study, the type of research is application-development and the evaluation methods are analytic and descriptive. 
Method of gathering data is documentation and surveys in the library.

\section{Theoretical Framework}

Urban planning can be considered as one of the most important connection point between urban management and citizens. On the other words urban management can realize the concept of citizenship through laws, regulations, urban planning and Job description for himself and other members.

Responding to the responsibilities and obligations, not only is the responsibilities of the citizens, but also is politicians and officials which have great responsibilities in this area. From this view, the necessity of collaboration between the citizens and the government and the citizens between each other in order to attain their rights is inevitable [4].

From the perspective of urban, citizenship rights is a relationship between the citizen, their rights and duties against each other and principles, purposes, duties and procedures. In this regards, city has been the main key of citizenship rights achieving. There are cities and healthy environment as fundamental rights of citizens and citizenship rights achieving is denied in the absence of city.

For experiencing the city and healthy environment as the basic citizenship rights, a detailed recognition of city, urban planning and its objectives, citizens, citizenship rights are necessary.

Certainly, healthy environment will be achieved by applying a suitable urban planning. Thus, in this study a specific fabric is designed. The diagram is indicated in Figure.1.

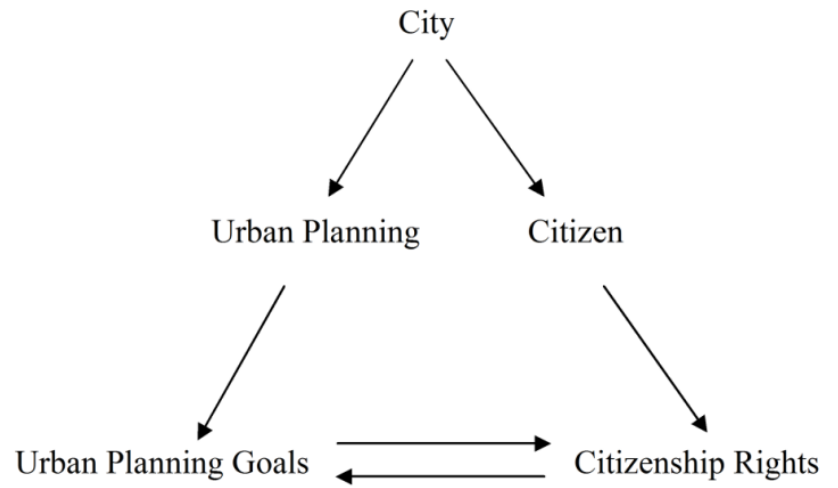

Figure 1. The theoretical Framework diagram

As shown in diagram1, two main components can be considered for city.

1. Citizen: citizens as main stakeholders of municipality, have some rights and obligations.

2. Urban planning: The urban planning by editing the rules and regulations and defining tasks for urban managers and citizens, causing real participation of citizens in the administration and interpretation of the rights of citizens.
3. Therefore, it can be said, citizens have real rights, because of living in the city, that urban planning should try to achieve its goal by defining the laws. To achieve this issue, without doubt, the definition and recognition of the city, citizens, civil rights, urban planning and its objectives are inevitable and should be properly scrutinize.

\subsection{Urban Definition}

There is not a general urban definition which all the researchers accept it. In this study two important definitions of urban are considered mainly. Urban is a phenomena of "where and when" which is created in a particular spot, evolved in the space and grown over the time. It causes that the city can transform the quantitative changes to its necessarily qualitative changes, at any time of history [5].

On the other hand, regarding to the sociological, urban is a desirable position for public institutions, promote cultural values, expansion, consolidation of social relations, the protection of human practices, home and local identities [6].

It is concluded that urban is the layer of citizen social life which must be tending more than other subject to achieve and promote the citizenship rights.

\subsection{Citizen and Citizenship Rights}

There are various definitions about citizens and citizenship rights, some of the important definitions are:

A native or naturalized member of a state or nation who owes allegiance to its government and is entitled to its protection or an inhabitant of a city or town, especially one entitled to its privileges or franchises.

In a legal terminology, citizen is a person who is connected to the government that's responsible for civil and political rights and on the other hand, obeying some duties for the government. This relationship is called citizenship. Citizenship rights and their duties are determined by the Islamic Republic of Iran's constitution and civil laws [7].

Citizen as a special concept of civil society is a person who is:

a. In reaction with social actions and other thoughts by voluntary membership in organizations and associations.

b. Besides understanding their rights, citizens realize that law is about protecting their rights [8].

Citizenship is defined based on Giddens as the people who live within the political boundaries which have the same functions and are considered as a part of the nation [9].

Citizenship" designating the legal status that allows a person to take part to start life by direct participation by referendum or indirect participation by delegating powers to the parliament as representatives of its exercise [10].

A citizenship right is a novel concept which focus on equality and justice and has a particular position in social, political and legal theories. If a citizen of a society has all civil and political rights, the concept of "citizenships" will occur [11]. 
Citizenship is not only related to the citizenship "rights and benefits" but also related to some obligations which have to be obeyed by citizens [12].

\subsection{Urban Planning and Its Objectives}

Urban, city and town planning, integrate land use planning and transportation planning to improve the built, economic and social environments of communities. It is clear that a suitable planning can help us to have a healthy city as the main context of human life and reactions. Progress and lack of progress of some various cities are related to their planning, monitoring and implementing. Changes to the planning process strategic urban planning over past decades have witnessed the metamorphosis of the role of the urban planner in the planning process.

Planning is a scientific and analytical activity, in order to achieve the target of attention. Urban planning is the welfare of citizens, by creating a better, more favorable, safer, easier, more efficient and more pleasant environment [13].

In this type of plan, according to the urban economic and functions, some parameters such as, land use, zoning, housing, traffic, green spaces in relation to the population were examined and analyzed[14].

Urban planning deals with a still larger environment, at a less detailed level and can include urban renewal by adapting urban planning methods to existing cities suffering from decay and lack of investment and are related to the development planning at regional level in a specific period of time[15].

Various purposes are represented in urban planning by the researchers. The following items are considered as the main objectives of urban planning based on the writer's opinions.

- Organizing the activities and functions

- Creating a more comfortable, better, easier and more effective environment for citizens

- Create a suitable environment for economic and social, sustainable development

- Improving the living and working conditions of the citizens.

- Establishing social justice.

- Promote the general Welfare.

- Optimal land use and maintain and enhance the quality of the physical environment and living space.

Undoubtedly, urban planning and targets are in conformity with the citizenship rights and proper planning in accordance with the demands of human society are underlying to achieve the citizenship rights in the community.

Iran was selected as a case study in this labor.

\subsection{Citizenship Rights Indicators}

According to the theoretical frameworks, proposed definitions and goals, citizenship rights indicators could be divided into 8 groups as shown in table 1 .
Table 1. Citizenship rights indicators

\begin{tabular}{|c|c|}
\hline NO & Citizenship rights indicators based on constitutional rights \\
\hline 1 & Equal rights \\
\hline 2 & Social impurity \\
\hline 3 & Good quality housing and freedom of choice Location \\
\hline 4 & Freedom of information and news \\
\hline 5 & Political and social freedom \\
\hline 6 & Freedom of occupation \\
\hline 7 & Education freedom \\
\hline 8 & Property sanctity \\
\hline
\end{tabular}

\section{Case Study Research}

\subsection{Islamic Republic of Iran}

Iran, (Islamic Republic of Iran), a country which is located in southwest Asia and in the Middle East, with an area of 1648195 square kilometers and has 75,149,669 population based on 1390 census.

This system of governance in Iran was made after the revolution of 1357 and the constitution was revised and ratified in 1358 and 1368, respectively.

\subsection{Citizenship Rights Achieving and the Solutions}

According to the research objectives and presented theoretical framework, the first step for case study is a comprehensive study on the constitution rights of Islamic Republic of Iran.

In this regard the most basic civil rights which is matches to one or more citizenship rights indicators. They are listed and presented in Table 2 .

As specified in Table 2, Constitution of the Islamic Republic of Iran has the principles which are matches to citizenship rights and focus on it. In this regard and to achieve the aim of this study which is explaining the effective parameters on urban planning for citizenship rights achieving, recommendations and methods for achieving to each of citizenship rights indicators by urban planners has been defined according to the types of programs. The results are indicated in table 3 .

Table 2. Citizenship right based on the constitution

\begin{tabular}{|c|c|c|}
\hline NO & The principle number & $\begin{array}{c}\text { A citizenship right, title based on the } \\
\text { constitution }\end{array}$ \\
\hline 1 & 20,19 & Equal rights \\
\hline 2 & 22,40 & Social impurities \\
\hline 3 & 31,33 & $\begin{array}{c}\text { Good quality housing and freedom } \\
\text { in residence selecting }\end{array}$ \\
\hline 4 & 24,25 & Freedom of information and news \\
\hline 5 & 26,27 & Political and social freedom \\
\hline 6 & 28 & Freedom of occupation \\
\hline 7 & 30 & Education freedom \\
\hline 8 & 46,47 & Property sanctity \\
\hline
\end{tabular}


Table 3. Presented recommendation for accessing the citizenship rights

\begin{tabular}{|c|c|c|}
\hline No & Citizenship rights & The recommended methods (by urban planning and designing) \\
\hline 1 & Equal rights & $\begin{array}{l}\text { Urban land use planning based on the real needs of human society } \\
\text { Creating the same urban infrastructure for citizens through the preparation of urban } \\
\text { projects }\end{array}$ \\
\hline 2 & Social Protection & $\begin{array}{c}\text { Creating the urban planning and regulation without citizenship right violation such as } \\
\text { nobility, ghosting } \\
\text { Justice and comprehensive urban planning for the citizens, without any vested interests } \\
\text { of specific individuals }\end{array}$ \\
\hline 3 & $\begin{array}{l}\text { Good quality housing and } \\
\text { freedom in residence } \\
\text { selecting }\end{array}$ & $\begin{array}{c}\text { Preparing and implementing housing plan } \\
\text { Required residential land used without any vested interests of specific individuals in } \\
\text { urban planning } \\
\text { Organizing and empowerment of urban neighborhoods }\end{array}$ \\
\hline 4 & $\begin{array}{l}\text { Information and news } \\
\text { freedom }\end{array}$ & $\begin{array}{c}\text { Urban spaces created for citizen interaction } \\
\text { Consideration of spaces in the city to provide news and information to citizens }\end{array}$ \\
\hline 5 & Political and social freedom & $\begin{array}{l}\text { Designing the spaces for residents gathering } \\
\text { Allocating public land use of the citizen social and political activities }\end{array}$ \\
\hline 6 & Freedom of occupation & $\begin{array}{c}\text { Allocating the land use related to the citizen, business and requirement in urban } \\
\text { planning }\end{array}$ \\
\hline 7 & Educational freedom & Allocating the educational land use with equal access for citizen in urban planning \\
\hline 8 & Property sanctity & Preserving the private sanctity in the preparation and implementing the urban plans \\
\hline
\end{tabular}

Table 4. The effective urban planning indicators for citizenship rights

\begin{tabular}{|c|c|c|c|}
\hline NO & Indicators & Residential land use planning & \multirow{2}{|c|}{$\begin{array}{c}\text { Urban land use } \\
\text { planning }\end{array}$} \\
\hline 1 & Residential land use & Land use planning related to residential use & Infrastructure and facilities, urban planning \\
\hline 2 & Nonresidential land use & Housing planning \\
\hline 3 & Urban infrastructure & Creation and improvement planning of urban public spaces \\
\hline 4 & Housing quality & Urban public spaces & \\
\hline 5 & &
\end{tabular}

\subsection{Determining the Urban Planning Parameters of Citizenship Rights}

Urban planning indicators which are comprehensive representative of citizenship rights methods were presented based on the research theoretical framework and case studies. The determined indicators are presented in Table 4.

It should be noted that housing is a basic requirement in the Constitution, so for Most of the land area devoted to this land use in the urban land use planning and the other land uses are identified as its related land uses. Thus, urban land use planning criteria are divided into two parts: residential and related land use.

\subsection{Prioritize Indicators of Urban Planning Based on AHP Model}

Undoubtedly, the numerical weight of citizenship rights indictors on citizenship rights achieving were not the same and each of them has different effects and roles on citizenship rights achieving. In this regards, prioritizing the indicators provide a shorter path to urban planners for achieving the goal.

In order to prioritize the effective citizenship rights indicators on citizenship rights achieving, Analytic hierarchy process evaluation method (AHP) and Expert choice software were used. Based on the weight of each indicator compared to 9 scale quantitative indicators together through time to compare binary options (Table 5) specified and the results are presented in Table 6.

Table 5. Time quantity 9 scales for comparing binary options

\begin{tabular}{|c|c|}
\hline Description & Rating (strongly preferred) \\
\hline Equally preferred & 1 \\
\hline Moderately preferred & 3 \\
\hline Strongly preferred & 5 \\
\hline Very strongly preferred & 7 \\
\hline Extremely preferred & 9 \\
\hline $\begin{array}{c}\text { Intermediate preferences (when } \\
\text { there are intermediate positions) }\end{array}$ & $2,4,6,8$ \\
\hline
\end{tabular}


Table 6. Time quantity 9 scales for comparing binary criteria

\begin{tabular}{|c|c|c|c|c|c|c|}
\hline $\begin{array}{c}\text { Criteria } \\
\text { weight } \%\end{array}$ & $\begin{array}{c}\text { Urban public } \\
\text { spaces }\end{array}$ & $\begin{array}{c}\text { Urban } \\
\text { housing }\end{array}$ & infrastructure & $\begin{array}{c}\text { Non-residential } \\
\text { land use }\end{array}$ & $\begin{array}{c}\text { Residential } \\
\text { land use }\end{array}$ & Residential land use \\
\hline 7.1 & $\frac{1}{4}$ & 1 & $\frac{1}{5}$ & $\frac{1}{3}$ & 1 & Nonresidential land use \\
\hline 16.1 & $\frac{1}{2}$ & 2 & $\frac{1}{3}$ & 1 & 3 & Urban infrastructure \\
\hline 42 & 2 & 4 & 1 & 3 & 1 & Urban housing \\
\hline 8.5 & $\frac{1}{3}$ & 1 & $\frac{1}{4}$ & $\frac{1}{2}$ & 4 & Urban public spaces \\
\hline 26.4 & 1 & 3 & $\frac{1}{2}$ & 2 & 4 & \\
\hline
\end{tabular}

\section{Conclusions}

One of the significant factors of social, political and legal topics of the modern body politic in the contemporary world is the lieu and the rights and privileges of citizens. Thus, in all modern societies, developing civil rights and how to realization of it, is one of the primary worries of the rulers and government agencies. It is so important which is one of united nation important agenda and meetings is devoted to the issue of human rights and civil rights in the macro and micro debate, respectively. According to the importance of the issue and the fact that most people live in cities in the world. In this paper, after the registration of civil rights, how to realization of citizenship rights through urban planning has been dissected.

The consequences are shown that, the impact of urban planning and objectives on citizenship rights is undoubtedly related to the correct and justice, urban planning in accordance with the demands of human company.

In the present study, after achieving to the citizenship rights indicators by theoretical frameworks and determine the Islamic republic of Iran constitution which are matched to these indicators and How to achieve them was assessed by designers and urban planners and finally the five indicators of urban land use planning (Residential land use planning, Land use planning related to residential use, Infrastructure and facilities, urban planning, Housing planning, Creation and improvement planning of urban public spaces) were selected as the main influencing urban planning indicators on citizenship rights achieving.

It's clear that the numerical weight of each criteria's were different with each other. Precedence and the grandness of the criteria's were determined according to the AHP model. Urban infrastructure and public spaces, with close to 70 percent had the more weight importance and precedence among other indicators. Undoubtedly, urban planners need special attention during the formulation of programs and plans.

In conclusion, in this field, the necessary framework for proper urban planning that would be suitable and worthy of citizenship rights were given.

\section{REFERENCES}

[1] S. Pourtahmasebi, A. Tajour, Citizenship rights and education in Nahjolbalagheh, Alavi research, Institute for Humanities and Cultural Studies, Vol.2, No.2, 1-23, 1390.

[2] R. Afzali, M. Hesam, Citizenship rights in Iran, Journal of economic and political information, Vol 279-280. 106-123.

[3] M. Ahmadi Tabatabaee, Citizenship rights emphasized the constitution of the Islamic Republic of Iran, Journal of the Islamic Revolution approach Vol.3, No.8, 3-18, 1388.

[4] M. Piri, N. Ghasemi, Judicial and legal review ad citizenship rights acts in the environment, Environmental Science and Technology, Vol.11, No.3, 205-212, 1388.

[5] M. Habibi, From the flux to the city, Tehran university press, Tehran, 8th Ed, 1387.

[6] H. Lotfi, F. Edalatkhah, M. Mirzae, Sh. Vazirpor, Urban management and its role in promoting the citizenship rights, Journal of human geoghraphy, Vol.2, No.1, 101-110, 1388.

[7] N. Shokri, Urbanization, rights and citizen responsibilities, Public administration Conference, Citizenship and organization development, Tehran municipality, 1386.

[8] Gh. Latifi, H. Ahmadi, Citizenship and participation urban planning, Journal of library and information, Social science month magazine, No.36, 55-63, 1389.

[9] E. Saraghi, L. Saki, D. Abolfathi, H. Maleki, Analysis of citizenship rights and its impact on the city and urban contemporary, Urban regional Conference, Citizen and urban management, Islamic Azad university, Malayer Branch, 1-15, 1389 .

[10] G. Nemtoi, C. Ignatescu, National Citizenship as Representative of European Citizenship, Procedia - Social and Behavioral Sciences Vol.149, 653 - 658, 2014.

[11] E. Mafi, M. Davoodi Nejad Moghaddam, M. Mabhoot, Principles of citizenship rights in the Islamic utopia, National conference of Islamic Urbanism and architecture, Khavaran University, Mashhad, 1-8, 1391.

[12] M.Alsan, Citizenship rights from the perspective of global citizen theory and Iran laws and regulations, Journal of Human Rights, Vol.3, No.6, 3-20, 1387.

[13] E. Shieh, Introduction to the principles of urban planning, Elmo Sanat University press, 34th Ed, Tehran, 1392.

[14] K. Hossen Zadeh Dalir, Reginal planning, Samt press, Tehran, 12 th Ed.

[15] K. Ziari, Principles and Methods of Regional Planning, Tehran university press, Tehran, 5 th Ed. 